\title{
Consideration Whether Hepatitis B Exists in Children Whose Mothers Suffer from Chronic Hepatitis B and These Mothers in Gestational Age
}

\author{
Kronik Hepatit B Enfeksiyonu Olan Annelerin Gebeliklerinde ve Çocuklarında Hepatit \\ B Enfeksiyonun Değerlendirilmesi
}

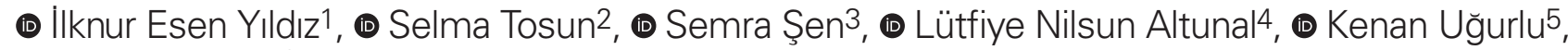 \\ (1) Ayşenur Bahşi6
}

${ }^{1}$ Recep Tayyip Erdoğan University Faculty of Medicine, Department of Infectious Diseases and Clinical Microbiology, Rize, Turkey

2 University of Health Sciences Turkey, Izmir Bozyaka Training and Research Hospital, Clinic of Infectious Diseases and Clinical Microbiology, Izmir, Turkey ${ }^{3}$ Celal Bayar University Faculty of Medicine, Department of Paediatric Infectious Diseases, Manisa, Turkey

4 University of Health Sciences Turkey, Istanbul Ümraniye Training and Research Hospital, Clinic of Infectious Diseases and Clinical Microbiology, Istanbul, Turkey 5 Gaziantep 25 Aralık State Hospital, Clinic of Infectious Diseases and Clinical Microbiology, Gaziantep, Turkey

6Manisa Merkez Efendi State Hospital, Clinic of Gynaecology, Manisa, Turkey

\begin{abstract}
Objectives: Perinatal and intrauterine transmission of the hepatitis B virus (HBV) represents a major factor, leading to the development of chronic infection. This study aimed to explore the status of mothers and their children for hepatitis $B(\mathrm{HB})$ infection during pregnancy and childhood, and whether active and passive immunoprophylaxis was administered to infants shortly after birth.

Materials and Methods: We performed multicenter, retrospective research on voluntary hepatitis B surface antigen (HBsAg)-positive mothers admitted to infectious diseases polyclinics was performed. Mothers and their children were queried by a questionnaire about their HB infection status. Data from the electronic data recording system was scanned retrospectively.

Results: Three hundred-one mothers and 616 children were included in the study. HBsAg was examined in $354(57.4 \%)$ of pregnancies. Of 91 children with HBsAg positivity, 83 were not applied active and passive immunoprophylaxis after birth. Eight 276 babies received both immune prophylaxes after birth were then detected as HBsAg positive. On HBV examination, 148 children
\end{abstract}

ÖZ

Amaç: Hepatit B virüsünün (HBV) perinatal ve intrauterin bulaşı, kronik enfeksiyonun gelişmesine yol açan önemli bir faktörü temsil etmektedir. Bu çalışmada, annelerin ve çocuklarının hamilelik ve çocukluk döneminde hepatit B (HB) enfeksiyonu için değerlendirilme durumlarını ve doğumdan hemen sonra bebeklere aktif ve pasif immünoprofilaksi uygulanıp uygulanmadığının araştııııması amaçlandı.

Gereç ve Yöntemler: Enfeksiyon hastalıkları polikliniğine başvuran gönüllü hepatit B yüzey antijeni (HBsAg)-pozitif annelere yönelik çok merkezli, retrospektif araştırma yaptık. Annelere ve çocuklarına HB enfeksiyonu durumları hakkında bir anket uygulandı. Elektronik veri kayıt sistemindeki verileri geriye dönük olarak tarandı.

Bulgular: Üç yüz bir anne ve 616 çocuk çalışmaya dahil edildi. HBsAg gebeliklerin 354'ünde $(\% 57,4)$ tetkik edildi. HBsAg pozitifliği olan 91 çocuğun 83'üne doğumdan sonra aktif ve pasif immünoprofilaksi uygulanmadığı saptandı. Doğumdan sonra her iki immün profilaksiyi de alan 276 bebekten 8'i HBsAg pozitif olarak tespit edildi. HBV incelemesinde, 148 çocuğun HBV ile karşılaştığı bulundu. HBsAg

Yıldız IE, Tosun S, Şen S, Altunal LN, Uğurlu K, Bahşi A. Consideration Whether Hepatitis B Exists in Children Whose Mothers Suffer from Chronic Hepatitis B and These Mothers in Gestational Age. Viral Hepat J. 2020;26:124-130.

This study received the poster second prize at the XIV National Hepatitis Congress.

Address for Correspondence: IIknur Esen Yıldız MD, Recep Tayyip Erdoğan University Faculty of Medicine, Department of Infectious Diseases and Clinical Microbiology, Rize E-mail: iesenyildiz61@gmail.com ORCID ID: orcid.org/0000-0003-2987-0483 Received: 24.02.2020 Accepted: 21.08.2020

${ }^{\circ}$ Copyright 2020 by Viral Hepatitis Society / Viral Hepatitis Journal published by Galenos Publishing House. 


\section{ABSTRACT}

were found to encounter the HBV. HBsAg positivity rate was significantly higher in children born before 1997

Conclusion: The remarkable decrease in HBsAg positivity of children reveals the efficacy of national vaccination. By informing both healthcare workers and society, awareness about examining pregnants for HBsAg during pregnancy should be increased.

Keywords: Pregnant, HBsAg, immune prophylaxis $\ddot{0 Z Z}$

pozitiflik oranı 1997'den önce doğan çocuklarda anlamlı olarak daha yüksek olarak belirlendi.

Sonuç: Cocukların HBsAg pozitifliğindeki dikkat çekici azalma, ulusal aşlamanın etkinliğini ortaya koymaktadır. Hem sağık çalışanlarını hem de toplumu bilgilendirerek, hamilelik sırasında HBsAg için gebelerin tetkik edilmesi konusunda farkındalık artırımalıdır.

Anahtar Kelimeler: Gebe, HBsAg, immün proflaksisi

\section{Introduction}

Hepatitis B virus (HBV) infection remains to be a significant global public health issue affecting more than 257 million people in the whole world $(1,2,3)$. By the World Health Organization (WHO), it was reported that one million people for reasons related to viral hepatitis have been dying every year, and there has been a $22 \%$ increase in deaths since 2000. WHO, for 2030, aims to reduce the number of hepatitis infections by $90 \%$ and mortality by $65 \%$, also suggests essential strategies $(2,3)$. One of these strategies is the prevention of transmission from mothers with hepatitis infection to the baby, which is one of the main ways to reduce the incidence of HBV in the community $(2,4,5)$. The perinatal or vertical transmission of the virus in pregnancy, birth, early infancy to babies of hepatitis B surface antigen ( $\mathrm{HBsAg}$ ) positive mothers plays a vital role in endemic infection and to develop chronic infection $(3,6)$. The administration of active and passive immunoprophylaxis [hepatitis B hyperimmune globulin ( $\mathrm{HBIG}$ ) with HBV vaccine] within the first 12-24 hours immediately after birth to infants of mothers with HBsAg positivity prevents $90-95 \%$ transmission of the HBV to the baby $(1,2)$. This application is, therefore, crucial to prevent both becoming chronic of the infection and complications of the infection by not being taken the virus at an early age $(2,4,6)$. Screening mothers for hepatitis B $(\mathrm{HB})$ infection in pregnancy and administering active and passive immune prophylaxis to their babies in the presence of $\mathrm{HB}$ is one of the most critical viral hepatitis prevention strategies of $\mathrm{WHO}$ to reduce the incidence of $\mathrm{HB}$ infection in the community $(3,5,7,8,9)$. Also, after examining and following up the pregnant for $\mathrm{HB}$, the initiation of antiviral therapy or prophylaxis, if necessary, and monitoring of exacerbations that may develop due to HB infection during and after pregnancy, are essential for the prevention of transmission. Perinatal transmission all over the world and in our country is one of the most common transmission ways of HBV infection $(3,8)$. The perinatal transition rate of $5-15 \%$ could be seen in babies of hepatitis $B$ e antigen (HBeAg) positive or high viral loaded pregnant women, in whom HBsAg positivity was detected despite appropriate active and passive immune prophylaxis $(10,11,12)$. The risk of transition from mother to baby is tried to be reduced further even in high viral loaded $(200000 \mathrm{IU} / \mathrm{mL}$ ) pregnant women in recent years by using antiviral medication in addition to active and passive immune prophylaxis $(13,14,15,16,17)$.

We aimed in our study to determine the status of evaluating the pregnants for HB infection during pregnancy, whether active and passive immunoprophylaxis was administered to infants immediately after delivery and then, whether HBV examination was made and immunity was developed in children of mothers against current HB infection, and to reveal the related deficiencies.

\section{Materials And Methods}

Our study was planned as a multicenter, retrospective, descriptive cross-sectional research, and it was held in five different provinces (Rize, Izmir, Gaziantep, Manisa, Istanbul) from five different regions of Turkey. The mothers with HBsAg positivity who were followed by infectious diseases and clinical microbiology clinics of tertiary universities or educational research hospitals or referred by obstetrics and gynaecology clinics were included in the study. Ethical permission: A multicenter study permit from the Ethics Committee University of Health Sciences Turkey, Izmir Bozyaka Training and Research Hospital (appoval number: 27.10.2015/2) and permission from the Republic of Turkey Public Health Agency (appoval number: 45202601) were obtained for the study.

\section{Collection of Data}

The study was conducted on HBsAg positive mothers admitted to infectious diseases polyclinics between 2015 and 2017 after obtaining their consent, by performing a questionnaire through the face-to-face interviews. Mothers whose children were born after 1991, and their children were included in the study. We also scanned files and evaluated the electronic registration data system of the study participants retrospectively.

\section{Data Collection Tools}

Besides the demographic data of mothers and their children, examinations performed and treatments administered during and after their pregnancy, and the follow-up status of their children was questioned. For this purpose, we asked the mothers whether they were examined for HBsAg during their pregnancy and whether vaccine and $\mathrm{HB}$ immunoglobulin was administered to their babies within the first 12-24 hours immediately after delivery. The questions regarding the screening of mothers for HBV were asked; besides, children too, were questioned about the immune status of them after the completion of three doses of HB vaccines. The current situation of their children for HBV acquisition was also re-examined. Relevant information that could not be obtained from subjects were tried to be reached from the patient files.

\section{Statistical Analysis}

SPSS for Windows 21.0 program was used for statistical analyses. Descriptive statistics and frequency distributions were 
calculated in line with the characteristics of the variables in the study. According to whether the data obtained were categorical or not and were independent or not, and the number of groups of the obtained data, the Pearson chi-square test, Student's t-test, and Mann-Whitney $U$ test was performed. For the comparison of more than two groups, we used ANOVA for parametric data and the Kruskal-Wallis test for non-parametric data. The statistical significance level was accepted as $p<0.05$.

\section{Results}

In our study, 301 mothers and 616 children were evaluated. The mean age of mothers was $38.6 \pm 7.5$ (19-64), and the mean age at diagnosis was detected to be $24.3 \pm 10.6$ (6-54). In 262 of 616 pregnancies, mothers were found to be not examined for hepatitis infection. The sociodemographic characteristics of mothers (data) were summarized in Table 1. The mean age of children was $12.8 \pm 6.6(2-28)$ years, and the female to male ratio was identified to be $295 / 321(47.8 \%, 52.2 \%)$. The sociodemographic characteristics (data) of children were given in Table 2.
When we questioned mothers, we learned that HBsAg had been examined in $57.4 \%$ of pregnancies. Furthermore, the HBV examination was done to only $294(47.7 \%)$ children at any time, while 96 (15.6\%) had no HBV examination until now. Of those children undergoing HBV examinations, 91 (20\%) were with HBsAg positivity, and 57 (14.5\%) had natural immunity. The status of being examined for HBV, the HBV examination results, and the status of vaccine and $\mathrm{HBIG}$ administration after birth in children were summarized in Table 3.

Despite the administration of active and passive immunoprophylaxis within the first 12-24 hours immediately after delivery, 8 (2.9\%) of 276 infants had HBsAg positivity. Based on the electronic registration data, we found the mothers of these children to be with HBeAg positivity and high HBV-DNA levels in their pregnancies. It was also determined that they had used medication, too, in their follow-up after their pregnancies. In the current study, HBsAg positivity was found to be significantly higher in children born before 1997 ( $n=34$ and \%37.2) $(p=<0.001)$. We observed the mothers of the majority of children who have HBsAg

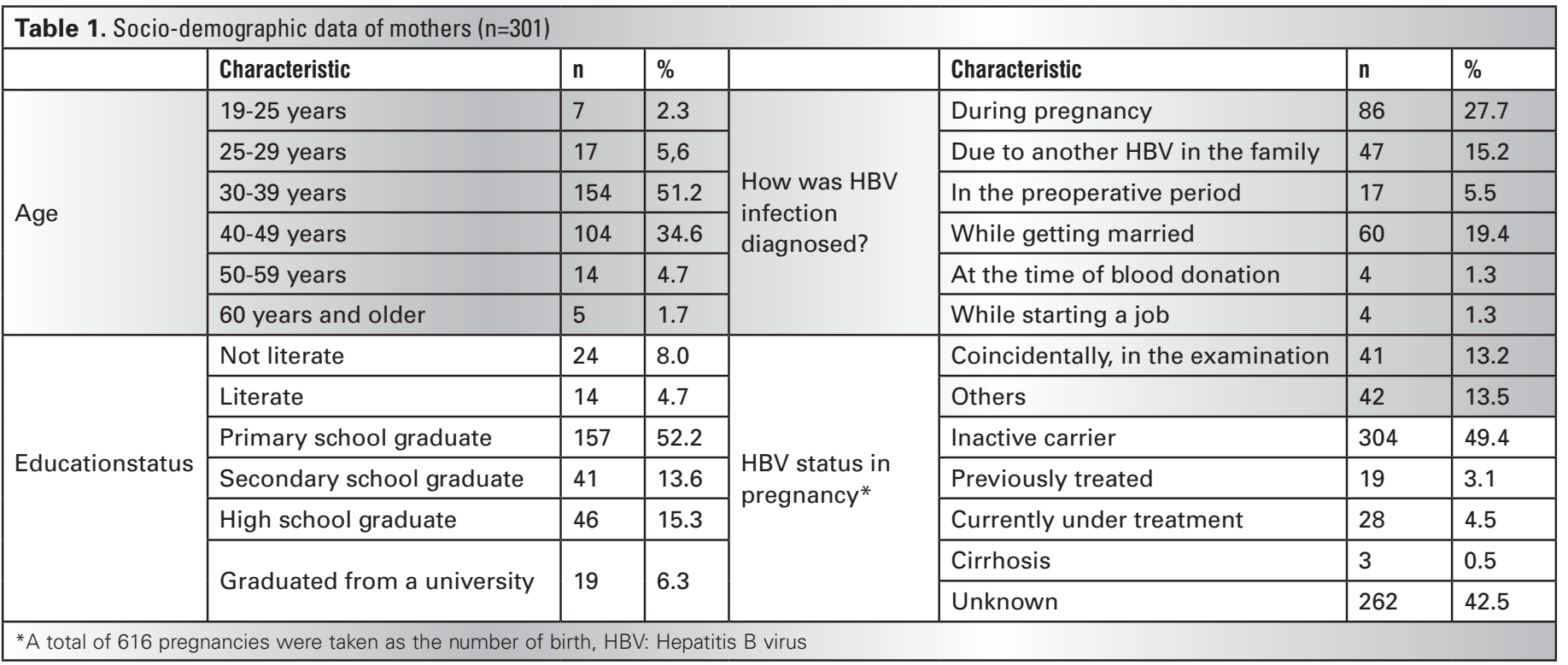

\begin{tabular}{|c|c|c|c|c|c|c|c|}
\hline & Feature & n & $\%$ & & Feature & n & $\%$ \\
\hline \multirow{5}{*}{ Age } & $1-6$ years & 156 & 25.9 & \multirow{4}{*}{$\begin{array}{l}\text { State of having received } \\
\text { vaccination or HBIG at birth }\end{array}$} & Vaccination & 154 & 25.0 \\
\hline & $6-12$ years & 197 & 32.8 & & Vaccination + HBIG & 276 & 44.8 \\
\hline & $13-18$ years & 149 & 24.8 & & Unknown & 84 & 13.6 \\
\hline & $19-23$ years & 41 & 6.8 & & None & 102 & 16.6 \\
\hline & $24-28$ years & 73 & 12.1 & \multirow{3}{*}{$\begin{array}{l}\text { State of having been given } \\
\text { vaccination card }\end{array}$} & Given & 420 & 68.2 \\
\hline \multirow{2}{*}{$\begin{array}{l}\text { Mode of } \\
\text { delivery }\end{array}$} & Spontaneous vaginal delivery & 420 & 68.2 & & Not given & 68 & 11.1 \\
\hline & $\mathrm{C} / \mathrm{S}$ & 196 & 31.8 & & Not remembered & 128 & 20.1 \\
\hline \multirow{3}{*}{$\begin{array}{l}\text { Place of } \\
\text { delivery }\end{array}$} & Hospital & 467 & 75.8 & \multirow{4}{*}{$\begin{array}{l}\text { State of having received } \\
\text { HBVexamination }\end{array}$} & At age one & 294 & 47.7 \\
\hline & Home & 18 & 2.9 & & After age one & 197 & 31.8 \\
\hline & Community clinic & 131 & 21.3 & & Never & 96 & 15.6 \\
\hline - & - & - & - & & Not remembered & 29 & 4.7 \\
\hline
\end{tabular}


positivity, not to be examined for HBsAg during pregnancy $146.2 \%$ not examined, $16.4 \%$ examined, 39.4\% unknown). Again, the vast majority of these children have not received vaccines and immunoglobulin ( $n=83$ and $91.2 \%$ ). The comparison of the clinical status of children, whose mother was positive for HBsAg during pregnancy by age in terms of hepatitis infection was summarized in Table 4.

\section{Discussion}

It is reported in various studies that the administration of active and passive immune prophylaxis to babies of mothers with $\mathrm{HBsAg}$ positivity in the first 12-24 hours of life immediately after birth prevents $90-95 \%$ transmission of the HBV to the infant $(1,2,18,19)$.

In our country, despite all efforts, in general, routine screening of $\mathrm{HBsAg}$ in pregnant women, administration of active or passive immune prophylaxis to the babies of mothers with HB infections, and then monitoring the immune status of those is not at the desired level (20). It is seen that the awareness and application of the "Prenatal Care Guide" created by the Ministry of Health and updated in 2014 in the field are quite low and that the HBsAg test is not requested enough for pregnant women in many institutions $(20,21)$. With this aim, by the Ministry of Health in 2018, Viral

\begin{tabular}{|c|c|c|c|c|c|c|c|c|c|c|}
\hline & \multicolumn{5}{|c|}{ State of having received HBV examination } & \multicolumn{5}{|c|}{ State of having received vaccination and HBIG after delivery } \\
\hline & $\begin{array}{l}\text { At age } \\
\text { one }\end{array}$ & $\begin{array}{l}\text { After } \\
\text { age one }\end{array}$ & $\begin{array}{l}\text { Does not } \\
\text { know }\end{array}$ & Never & Total & Vaccinated & $\begin{array}{l}\text { Vaccine } \\
+ \text { HBIG }\end{array}$ & $\begin{array}{l}\text { Does not } \\
\text { know }\end{array}$ & None & Total \\
\hline Anti-Hbs positive & 167 & 105 & 1 & 0 & 273 & 39 & 165 & 23 & 46 & 273 \\
\hline Immune & 48 & 9 & 0 & 0 & 57 & 21 & 26 & 5 & 5 & 57 \\
\hline HBsAg positive & 57 & 34 & 0 & 0 & 91 & 28 & 8 & 19 & 36 & 91 \\
\hline Anti-HBc IgG positive & 2 & 1 & 0 & 0 & 3 & 1 & 1 & 0 & 1 & 3 \\
\hline $\mathrm{Kr} \mathrm{HBV}$ on treatment & 1 & 2 & 0 & 0 & 3 & 1 & 0 & 0 & 2 & 3 \\
\hline Ex & 0 & 1 & 0 & 0 & 1 & 0 & 0 & 0 & 1 & 1 \\
\hline Not remembered & 8 & 29 & 28 & 96 & 161 & 64 & 62 & 31 & 4 & 161 \\
\hline HBV negative & 11 & 16 & 0 & 0 & 27 & 0 & 14 & 6 & 7 & 27 \\
\hline Total & 294 & 197 & 29 & 96 & 616 & 154 & 276 & 84 & 102 & 616 \\
\hline
\end{tabular}

\begin{tabular}{|c|c|c|c|c|c|c|c|c|}
\hline & & $\begin{array}{l}1991- \\
1997\end{array}$ & $\begin{array}{l}1998- \\
1999\end{array}$ & $\begin{array}{l}2000- \\
2005\end{array}$ & $\begin{array}{l}2006- \\
2011\end{array}$ & $\begin{array}{l}2012- \\
2017\end{array}$ & Total & p \\
\hline \multirow{9}{*}{ HBV state } & Anti-HBs positive & 10 & 16 & 70 & 98 & 79 & 273 & \multirow{9}{*}{$<0.001$} \\
\hline & Immune & 13 & 2 & 8 & 20 & 14 & 57 & \\
\hline & HBsAg positive & 34 & 12 & 29 & 14 & 2 & 91 & \\
\hline & Isolated anti-HBc IgG & 0 & 0 & 1 & 1 & 1 & 3 & \\
\hline & Chronic HBV treatment & 3 & 0 & 0 & 0 & 0 & 3 & \\
\hline & Ex & 0 & 0 & 0 & 1 & 0 & 1 & \\
\hline & Not examined & 9 & 11 & 31 & 54 & 56 & 161 & \\
\hline & HBV negative & 4 & 0 & 10 & 9 & 4 & 27 & \\
\hline & Total & 73 & 41 & 149 & 197 & 156 & 616 & \\
\hline \multirow{5}{*}{$\begin{array}{l}\text { State of having received } \\
\text { vaccination-HBIG at delivery }\end{array}$} & Not vaccinated & 17 & 7 & 34 & 62 & 34 & 154 & \multirow{5}{*}{$<0.001$} \\
\hline & Vaccine + HBIG & 5 & 9 & 47 & 102 & 113 & 276 & \\
\hline & None & 35 & 15 & 36 & 16 & 0 & 102 & \\
\hline & Unknown & 16 & 10 & 32 & 17 & 9 & 84 & \\
\hline & Total & 73 & 41 & 149 & 197 & 156 & 616 & \\
\hline \multirow{5}{*}{$\begin{array}{l}\text { State of having received HBV } \\
\text { examination }\end{array}$} & At age one & 41 & 15 & 61 & 102 & 75 & 294 & \multirow{5}{*}{0.01} \\
\hline & After age one & 25 & 17 & 61 & 49 & 44 & 196 & \\
\hline & Unknown & 1 & 2 & 5 & 8 & 13 & 29 & \\
\hline & Never & 6 & 7 & 22 & 38 & 24 & 97 & \\
\hline & Total & 73 & 41 & 149 & 197 & 156 & 616 & \\
\hline
\end{tabular}


Hepatitis Prevention and Control Program was put into effect, and performing the HBsAg test for pregnant women has been made compulsory by no longer being a recommendation $(5,8)$.

No studies are examining whether the $\mathrm{HB}$ vaccine and HBIG prophylaxis could be administered together or separately. In our study, the rates of administering alone $\mathrm{HB}$ vaccine to babies after birth were $25 \%(n=154)$. In contrast, the rate of administering vaccine and immune globulin was found at $44 \%$ ( $n=276)$. In $55.6 \%$ ( $n=340$ ) of pregnancies, no immunoglobulin was applied, or whether applied or not of those were identified to be unknown. Some of the mothers even stated that they heard this expression for the first time. This situation suggests the insufficiencies in efforts leading pregnant women to be followed up and informed. In this context, a multidisciplinary joint action by all healthcare professionals, primarily including the clinicians working at Family Medicine, Obstetrics and Gynecology, and Infectious Diseases Clinics, is thought to be going to increase awareness. First, informative training for HBV examination during pregnancy should be given to pregnant women. Second, the control of the mother and child monitoring and the support of hospital administrations in eliminating the related deficiencies need to be increased. Third, intervention commissions should be established, and audits and feedback should be conducted. In this way, we think that both the rates of making the diagnosis of $\mathrm{HB}$ infection and the rates of administration of active and passive immunoprophylaxis to newborns could be increased. In Koruk et al.'s (22) intervention research from our country to prevent $\mathrm{HB}$ infection, the informative education, the identification of the deficiencies and taking the relevant measures, and acting together of all healthcare professionals, of hospital management, and public cooperation have been seen to yield successful results. The rate of immunoglobulin administration, which was $28.2 \%$ before that study, increased 5.8 times after the intervention, whereas that of vaccine administration increased two times $(22,23)$. Such practices need to be increased nationwide.

Vaccines protecting the health of the entire society, especially children, is the most effective method of preventing diseases in terms of cost and reliability $(2,3,12,20,22,24,25,26)$. Thanks to widespread vaccination campaigns, with vaccination studies carried out in one of the poorest countries in the world, 6.4 billion people survived between 2011-2020, and treatment costs seemed to decrease (9). HB infection is one of the primary vaccinepreventable diseases. Co-administration of active and passive immunoprophylaxis enhance immune protection. In our study, the determination of HBsAg positivity in only $\% 2,9(n=8)$ of infants who received the vaccine and hyper immunoglobulin prophylaxis proved such co-administration to be quite effective in preventing HBV transmission. The relationship between anti-HBS positivity in infants and increased postpartum immunoprophylaxis over the years was found to be statistically significant. Other studies, too, described the efficacy of the application of $\mathrm{HB}$ immunoglobulin with the vaccine to increase protection $(18,23,27,28,29)$. In Lee et al.'s (18) research, HB infection has been shown to develop much less frequently in vaccine or vaccine plus hyper immunoglobulin prophylaxis administered group compared to the placebo or untreated group. Again, $\mathrm{Yi}_{i}$ et al. (28) reported in their study that $\mathrm{HBIG}$ and vaccine combination reduced the rate of viral transmission from mother with $\mathrm{HBeAg}$ positivity to baby from $90 \%$ to $3-7 \%$. HBsAg incidence with universal vaccination of infants was, moreover, noted to fall from $9-12 \%$ to less than $1 \%$; besides, the protective efficacy of the $\mathrm{HB}$ vaccine with $\mathrm{HBIG}$ administration was shown to increase to $90-95 \%$ (30). In the research of Pande et al. (25), six babies from 259 babies born from HBeAg positive mothers had hepatitis infection, and they observed those babies be in the group without active and passive immunoprophylaxis (24). In our country, after the HB vaccine has been available and entered the calendar, although the incidence of HBV has been declared to decrease, no studies have been encountered in literature, documenting the rate of passive immune prophylaxis (24). At the same time, proper and effective administration of active and passive immunoprophylaxis remarkably prevents to get the HBV in infancy or early childhood and reduces becoming infection chronic and the deaths associated with HB that may develop in advanced ages $(12,25,31)$.

The vaccine and HBIG immunoprophylaxis in the prevention of transmission of HBV are 90-95\% effective; however, especially in pregnant women with high viral load and $\mathrm{HBeAg}$ positivity, there is a $5-10 \%$ viral transmission $(4,11,12)$. In the study of Farmer et al. (10), despite vaccination and HBIG immune prophylaxis, protection was accounted for $81 \%$. Whereas occult HB infection in Pande et al.'s (25) study developed at $64 \%$, the majority of these patients were in the group receiving active and passive immunoprophylaxis. Those results of several studies mentioned above support the requirement for giving antiviral medication to pregnant women, particularly with $\mathrm{HBeAg}$ positive and viral load $>107-8$. Many other guides and studies today recommend, too, the use of oral antivirals, especially in subjects with $\mathrm{HBeAg}$ positivity and high viral load (HBV-DNA >107-8) and in subjects, whom liver damage begins $(13,14,15,16,17)$.

Follow-up of babies after birth is important in terms of $\mathrm{HB}$ infection and immunization. In our country, few studies are examining immune prophylaxis and then the immune status of the baby against $\mathrm{HB}$ infection, and our research is one of them (24). In our trial, both the follow-up of the babies who were given immune prophylaxis could not be done enough, and their immune controls could not be screened adequately in the first year. HB infection has been detected in 34 of 197 children who were examined in later ages, but not being examined in the first year of infancy. Moreover, it has been stated that 17 of the children examined have not developed immunity, and booster doses have been made. This situation on the field suggests that there are deficiencies in the monitoring of mothers and children with $\mathrm{HB}$ infection. In our study, under the influence of National Viral Hepatitis Vaccination Programs, although the number of babies with HBsAg positivity has decreased over the years, the status of being examined mothers for the presence of $\mathrm{HB}$ infection during pregnancy and the follow-up of their babies' immune status one year after birth was determined to be not enough. Also, awareness of whether hyperimmune globulin prophylaxis was applied to infants or not was insufficient, and we saw troubles in the storage of documents or cards indicated immune prophylaxis had been done. The consciousness levels of mothers about the presence, follow-up, treatment, and prevention of $\mathrm{HB}$ infection are required to be 
Peer-review: Externally peer-reviewed.

\section{Authorship Contributions}

Concept: Design: S.T., Data Collection or Processing: I.E.Y., S.T., S.S.., L.N.A., K.U., A.B., Analysis or Interpretation: I.E.Y., Literature Search: S.T., Writing: I.E.Y.

Conflict of Interest: Authors declare no conflict of interest.

Financial Disclosure: There was no aid and sponsor for this study. application of the following recommendations could, therefore, reduce the frequency of $\mathrm{HB}$ infection among mothers and babies: 1 - acting all together of family physicians, pediatricians, gynecology and infection clinics, and all healthcare professionals, especially hospital management, 2- the identification of deficiencies and the establishment of intervention commissions, 3- organizing training and ensuring continuity of that to increase the level of knowledge of the entire society.

\section{Strength of the Study}

Our study is is the first multicenter study conducted in our country, examining the follow up of mothers with HB infection, whether babies are given both hepatitis vaccine and HBIG at birth, and the current status of children in terms of HB infection. The identification of deficiencies and making new arrangements even partially in the monitoring of $\mathrm{HB}$ infection in mothers and their babies could shed light on and contribute to future studies.

\section{Study Limitations}

Based on information from file scans and electronic data records, mothers evaluated for $\mathrm{HB}$ in their pregnancies were observed to be examined only in terms of HBsAg. Although the results were positive for HBsAg in most of them, deficiencies were found in requesting and examining for $\mathrm{HBeAg}$ and $\mathrm{HBV}$-DNA. This was one of the limitations of our study and caused babies born from $\mathrm{HBeAg}$ positive mothers not to be compared with babies born from HBeAg negative mothers. Also, since HBV-DNA data are not available in most pregnancies, no comparison could be made in terms of viral load in children. Moreover, the study is limited to five centers and does not reflect the country. The number of data needs to be supported by reflecting the whole country and with patient information, where all HB examinations are regularly monitored.

\section{Conclusion}

The follow-up of mothers and babies is not at the desired level in terms of preventing HB infection. Awareness should, therefore, be raised by eliminating related deficiencies.

\section{Ethics}

Ethics Committee Approval: A multicenter study permit from the Ethics Committee University of Health Sciences Turkey, Izmir Bozyaka Training and Research Hospital (appoval number: 27.10.2015/2) and permission from the Republic of Turkey Public Health Agency (appoval number: 45202601) were obtained for the study.

Informed Consent: The study was conducted on HBsAg positive mothers admitted to infectious diseases polyclinics between 2015 and 2017 after obtaining their consent, by performing a questionnaire through the face-to-face interviews.

\section{References}

1. Han GR, Cao MK, Zhao W, Jiang HX, Wang CM, Bai SF, Yue X Wang GJ, Tang X, Fang ZX. A prospective and open-label study for the efficacy and safety of telbivudine in pregnancy for the prevention of perinatal transmission of hepatitis B virus infection. J Hepatol. 2011;55:1215-1221.

2. Thomas DL. Global Elimination of Chronic Hepatitis. N Engl J Med. 2019;380:2041-2050.

3. World Health Organization. Global hepatitis report, 2017.

4. World Health Organization. Guidelines for the prevention, care and treatment of persons with chronic hepatitis B infection. https://www.who.int/hiv/pub/hepatitis/hepatitis-b-guidelines/en/

5. Republic of Turkey Ministry of Health. Turkey Viral Hepatitis Prevention and Control Program (2018-2023). 2018.

6. Celen MK, Mert D, Ay M, Dal T, Kaya S, Yildirim N, Gulsun S, Barcin T, Kalkanli S, Dal MS, Ayaz C. Efficacy and safety of tenofovir disoproxil fumarate in pregnancy for the prevention of vertical transmission of HBV infection. World J Gastroenterol. 2013;19:9377-9382.

7. World Health Organization. Hepatitis B vaccines: WHO position paper, July 2017 - Recommendations. Vaccine. 2019;37:223-225.

8. Turkey Viral Hepatitis Diagnosis and Treatment Manual, 2017.

9. Ozawa S, Stack ML, Bishai DM, Mirelman A, Friberg IK, Niessen L, Walker DG, Levine OS. During the "decade of vaccines," the lives of 6.4 million children valued at $\$ 231$ billion could be saved. Health Aff (Millwood). 2011;30:1010-1020.

10. Farmer K, Gunn T, Woodfield DG. A combination of hepatitis B vaccine and immunoglobulin does not protect all infants born to hepatitis B e antigen positive mothers. N Z Med J. 1987;100:412 414

11. Grosheide PM, del Canho R, Heijtink RA, Nuijten AS, Zwijnenberg J, Bänffer JR, Wladimiroff YW, Botman MJ, Mazel JA, de Gast $\mathrm{GC}$, et al. Passive-active immunization in infants of hepatitis $\mathrm{Be}$ antigen-positive mothers. Comparison of the efficacy of early and delayed active immunization. Am J Dis Chil. 1993;147:1316-1320.

12. Nelson NP, Jamieson DJ, Murphy TV. Prevention of Perinatal Hepatitis B Virus Transmission. J Pediatric Infect Dis Soc. 2014;3(suppl 1):7-12.

13. Terrault NA, Lok ASF, McMahon BJ, Chang KM, Hwang JP, Jonas MM, Brown RS Jr, Bzowej NH, Wong JB. Update on prevention, diagnosis, and treatment of chronic hepatitis B: AASLD 2018 hepatitis B guidance. Hepatology. 2018;67:1560-1599.

14. European Association For The Study Of The Liver. EASL clinical practice guidelines: Management of chronic hepatitis B virus infection. J Hepatol. 2012;57:167-185.

15. Li W, Jia L, Zhao X, Wu X, Tang H. Efficacy and safety of tenofovir in preventing mother-to-infant transmission of hepatitis B virus: a meta-analysis based on 6 studies from China and 3 studies from other countries. BMC Gastroenterol. 2018;18:121.

16. Wang L, Kourtis AP, Ellington S, Legardy-Williams J, Bulterys M. Safety of tenofovir during pregnancy for the mother and fetus: a systematic review. Clin Infect Dis. 2013;57:1773-1781.

17. Tavakolpour S, Darvishi M, Mirsafaei HS, Ghasemiadl M. Nucleoside/nucleotide analogues in the treatment of chronic 
Yildız et al.

hepatitis B infection during pregnancy: a systematic review. Infect Dis. 2018;50:95-106

18. Lee C, Gong Y, Brok J, Boxall EH, Gluud C. Effect of hepatitis B immunisation in newborn infants of mothers positive for hepatitis B surface antigen: systematic review and meta-analysis. BMJ. 2006;332:328-336.

19. Doğan $Y$, Aygün $D$, Akarsu $S$, Yılmaz $E$, Kabakus N. The role of immunoprophylaxis in prevention of vertical transmission of hepatitis B infection in cases who were admitted to Firat Medical Center. Turk Arch Pediatr. 2007;42:70-73.

20. Tosun S. Dünyada ve Türkiye'de viral hepatit B Epidemiyolojisi. In: Rahmet Güner TF, editors. Viral Hepatit 2018. Viral Hepatitle Savaşım Derneği Yayını. Istanbul: Istanbul Medikal Sağlık ve Yayınclık; 2018, p.13-48.

21. Republic of Turkey Ministry of Health. Prenatal Care Guide. 2014.

22. Koruk I, Tekin Koruk S, Çopur AÇ, Şimsek S et al. An Intervention Study to Improve HBsAg Testing and Preventive Practices for Hepatitis B in an Obstetrics Hospital. TAF preventive medicine bulletin. 2011:10:287-292.

23. Arısoy ES, Ciftçi E, Hacımustafaoğlu M, Kara A, Kuyucu N, Somer A, Vardar F. Clinical practical recommendations for Turkish national vaccination schedulefor previously healthy children (National Vaccination Schedule) and vaccines not included in the schedule. J Pediatr Inf. 2015;9:1-11.

24. Tosun S. Hepatit B așılaması ve ülkemizdeki hepatit B aşılama sonuçları. Tabak F, Güner R (editörler) Viral Hepatit Kitabı. Viral Hepatitle Savaşım Derneği Yayını. Istanbul: Istanbul Medikal Yayıncılık; 2018:253-266
25. Pande C, Sarin SK, Patra S, Kumar A, Mishra S, Srivastava S, Bhutia K, Gupta E, Mukhopadhyay CK, Dutta AK, Trivedi SS. Hepatitis B vaccination with or without hepatitis $B$ immunoglobulin at birth to babies born of HBsAg-positive mothers prevents overt HBV transmission but may not prevent occult HBV infection in babies: a randomized controlled trial. J Viral Hepat. 2013;20:801-810.

26. Kumar M, Singh T, Sinha S. Chronic hepatitis B virus infection and pregnancy. J Clin Exp Hepatol. 2012;2:366-381.

27. Beasley RP, Hwang LY, Lee GC, Lan CC, Roan CH, Huang FY, Chen $\mathrm{CL}$. Prevention of perinatally transmitted hepatitis $\mathrm{B}$ virus infections with hepatitis B immune globulin and hepatitis B vaccine. Lancet. 1983;2:1099-1102.

28. Aslam A, Campoverde Reyes KJ, Malladi VR, Ishtiaq R, Lau DTY. Management of chronic hepatitis B during pregnancy. Gastroenterol Rep (Oxf). 2018;6:257-262.

29. Yi P, Chen R, Huang Y, Zhou RR, Fan XG. Management of motherto-child transmission of hepatitis $B$ virus: Propositions and challenges. J Clin Virol. 2016;77:32-39.

30. Gülcü S, Arslan S. Vaccine Application on Children: A Current Review. Journal of Duzce University. 2018;8:34-43.

31. Centers for Disease Control and Prevention. Hepatitis B virus: a comprehensive strategy for eliminating transmission in the United States through universal childhood vaccination: recommendations of the Immunization Practices Advisory Committee (ACIP). MMWR Morbidity and Mortality Weekly Report. 1991;40:1-19. 